\title{
EFFECTIVENESS OF RUQYAH SYAR'IYYAH ON PHYSICAL DISEASE TREATMENT IN RIAU PROVINCE
}

\author{
Adynata and Idris \\ UIN Sultan Syarif Kasim Riau \\ Adynata@uin-suska.ac.id
}

\begin{abstract}
Ruqyah Syar'iyyah is one of Sunnah Prophet Muhammad in treating diseases and disorders syaithan, that is by reciting Al-Qur'an verses and praying. Most Muslims understand that ruqyah Syar'iyyah is only effectively treat non-medical disease or illness caused by psychiatric disorders and jin, whereas medical illness to be treated by medical means, Though al-Qur'an Surat al-Isra'verses 82 mentions that al-Qur'an is as a bidder (a cure) and a mercy for believers without distinction of medications for non-medical or medical illness. Based on the research of writer in 2015, there are two methods ruqyah Syar'iyyah in Riau Province, which is manual method and practical Qur'anic Healing method. In fact, there are many chronic medical illnesses cannot be treated by doctors, but these diseases can be treated and cured by ruqyah without being accompanied by medication. Thus, ruqyah Syar'iyyah is not only effectively treat mental illness, but also effectively treat medical ailments.
\end{abstract}

Keywords: Ruqyah Syar'iyyah, Physical Disease Treatment and Riau Province.

\begin{abstract}
Abstrak
Ruqyah Syar'iyyah merupakan salah satu Sunnah Rasulullah SAW dalam mengobati penyakit dan gangguan syaithan, yaitu dengan cara membacakan ayat-ayat al-Qur'an dan doa-doa. Kebanyakan umat Islam memahami bahwa ruqyah Syar'iyyah hanya efektif mengobati penyakit non medis atau penyakit yang disebabkan oleh gangguan kejiwaan dan jin, sedangkan penyakit medis harus diobati dengan cara medis. Padahal ayat al-Qur'an dalam surat alIsra': 82 menyebutkan bahwa al-Qur'an adalah sebagai penawar (obat) dan rahmat bagi orang beriman tanpa membedakan obat bagi penyakit medis atau non medis. Berdasarkan penelitian penulis tahun 2015, terdapat dua metode ruqyah Syar'iyyah di Provinsi Riau, yakni metode manual dan metode praktis Qur'anic Healing. Ternyata betapa banyaknya penyakit medis kronis yang tidak dapat diobati oleh para dokter, namun penyakit-penyakit tersebut dapat diobati dan sembuh dengan cara ruqyah tanpa disertai dengan obat-obatan medis. Dengan demikian ruqyah Syar'iyyah bukan hanya efektif mengobati penyakit kejiwaan, tetapi juga efektif mengobati penyakit medis.
\end{abstract}

Kata kunci: Ruqyah Syar'iyyah, Pengobatan Penyakit Fisik, dan Provinsi Riau.

\section{Introduction}

Ruqyah Syar'iyyah is one of Sunnah of the Prophet Muhammad in treating diseases and disorders of syaithan by reciting al-Qur'an verses and praying as understood from verses and Hadits. Ruqyah Syar'iyyah is not only for mental 
illness treatment or disorder jin as understood by societies, but also as physical illness treatment. It is understood from the arguments of al-Qur'an and al-Sunnah, the opinion of the scholars and the experience of ruqyah person, such as:

1. Allah says in Surah al-Isra' verse 82:

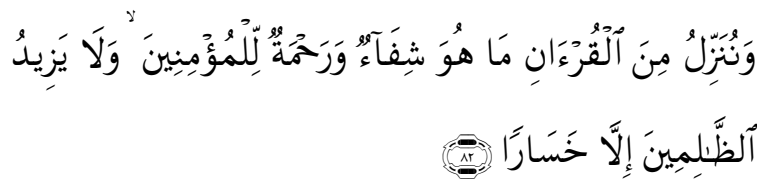

And We send down of the Qur'an that which is healing and mercy for the believers, but it does not increase the wrongdoers except in loss (QS. al-Isra': 82).

In verse mentioned that al-Qur'an serves as an antidote or cure of disease. Al-Qurthubi mentions that opinion of some scholars about the meaning of antidote refers to a cure for the disease Zahir or physically by means of ruqyah or prays for help to Allah SWT. ${ }^{1}$ In addition, there are no arguments specializing meaning of antidote is confined to psychiatric disease and jin disorders.

2. Hadith of the Prophet by Abu Khuzamah

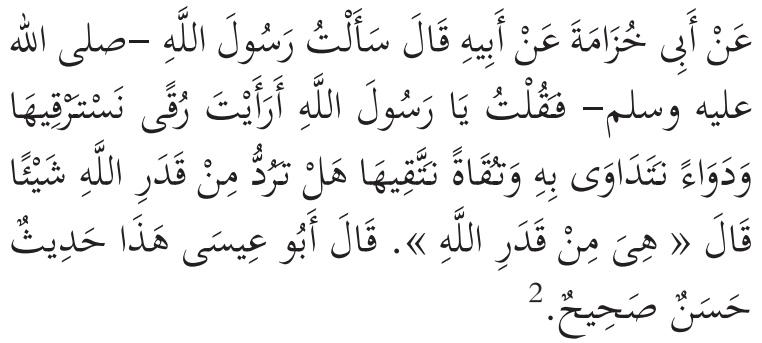
"From Abi Khuzamah from his father said, I asked the Prophet Muhammad," $O$ Messenger of Allah, What is your opinion about lafaz that we used as ruqyah and we treated it as well as the words of praying to seek protection or maintenance? Does that mean rejecting God's will? He replied: "It

\footnotetext{
${ }^{1}$ Abu Abdillah Muhammad bin Ahmad bin Abi Bakr bin Farh al-Anshariy al-Khazrajiy Syams al-Din al-Qurthubi, called al-Qurthubi, al-Jami' li Ahkam al-Qur'an, Juz 10 (Kairo: Dar al-Kutub al-Mishriyyah, 1964), 316.

${ }^{2}$ Muhammad bin Isa Abu Isa al-Turmuzi al-Sulamiy, al-Jami' al-Shahih Sunan al-Turmuzi, Juz 4 (Beirut: Dar Ihya' al-Turats al-“Arabiy, t.th), 399.
}

includes acts of God" (HR. al-Turmuzi), Abu Isa said this Hadits Hasan Saheeh.

In the hadits above, a companion asked the Prophet SAW about ruqyah or incantations were used as medicine illness without mentioning whether physical or mental illness, whether it amend acts of God or not, then he replied that treated in this way was included on the destiny of God. Thus, it is understood that ruqyah can become a drug for psychiatric diseases, disorders jin and physical illnesses.

3. Hadith of the Prophet Muhammad, narrated by Imam Muslim from Jabir:

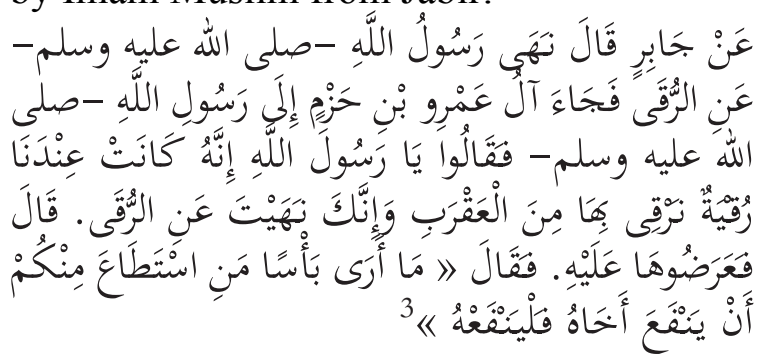

"From Jabir said, the Prophet SAW forbade ruqyah, then Amr bin Hazm family came to Rasulullah SAW., and said," O Messenger of Allah, we have ruqyah (incantation) from scorpion stings, while you have banned ruqyah. Amr said, "then they showed its ruqyah to him." Then the Prophet SAW said, I see no harm to anyone among you who is able to provide benefits to his brother then give” (HR. Muslim).

In hadith above, the Prophet Muhammad SAW allow Amr families did ruqyah against scorpions, meant to sting. Scorpions are venomous and stings certainly bring pain to the physical, after seeing ruqyah or incantation that is read by Amr family and did not contain things that are prohibited,

\footnotetext{
${ }^{3} \mathrm{Abu}$ al-Husain Muslim bin al-Hajjaj bin Muslim al-Qusyairiy al-Nisaburiy, Shahih Muslim, Jilid 7 (Beirut: Dar al-Jil Beirut and Dar al-Afaq al-Jadidah, t.th), 19.
} 
then he allowed it.

4. The views of Ibn Qayyim al-Jauziy, that ruqyah is not only to disorders jin and treat psychiatric, but also physical disorders. He said that one ruqyah reading taught by the Prophet SAW is QS. al-Falaq containing isti'azah to God from bad of all beings. So isti'azah here included requests kept away from physical disease, psychiatric disorders and syaithan through sorcerers or genie without a request sorcerer. ${ }^{4}$

5. Scientific studies mention the influence of praying therapy and its effectiveness in physical illness treatment.

Ruqyah therapy medically in recited verses or praying from al-Qur'an and al-Sunnah has influence in physical healing. Comparable with ruqyah therapy, praying therapy has been investigated its effectiveness in physical healing. Dossey, the doctor graduated from University of Texas explained that after gathering some research on praying therapy, he explained that prayer in fact can control cancer cells, cells boosters, cell, blood cells, enzymes, bacteria, fungi, etc. In line with Dossey, William G. Braud, director of research at the Institute of Transpersonal Psychology in Palo Alto reported that the man is capable of affecting the mentally and from a distance, a variety of biological targets such as bacteria, yeast colonies, motile algae (henbane), plants, protozoa, larva, woodlice (a kind of wood lice), ants, chickens, rats, cats, dogs, also preparations of cells (blood cells, neurons, cancer cells) and enzyme activity. On human targets, for example, affect of eye movements, motor movements, electro-dermal activity, platismografic

${ }^{4}$ Muhammad bin Abi Bakar bin Ayyub bin Sa'd Syams al-Din Ibn Qayyim al-Jauziyah, Zad al-Ma'ad fi Hady Khair al-'Ibad, Juz 4 (Beirut: Muassasah al-Risalah, 1994), 176. activity, breathing, and brain rhythms. This indicates that praying or activities of the human mind can affect creatures, including health. Furthermore Dadang Hawari states that a study of 393 heart patients at San Francisco showed that the group of patients whose treatment is coupled with praying therapy very few experienced complications, while without using praying therapy was a lot of complications from heart disease. Then, $\mathrm{Tb}$. Erwin Kusuma, a psychiatric specialist at Prorevital clinic stated water that has been given a praying will change the molecular structure and can be used as medicine. In line with the opinion of $\mathrm{H}$. Tb. Erwin, a Japanese study conducted by Emoto showed that structure of water molecules would change if given the words or sounds. He then explained that the human body is approximately 70 percent water. So there will be changes when given a word, sound, or praying. Water structural changes in the body are affecting the level of health. Several studies on the effects of praying on health before, indirectly, to prove that ruqyah therapy, praying from al-Qur'an and Sunnah affect the healing of physical illness. $^{5}$

\section{The experience of ruqyah person}

The writer has done research at Surabaya Ruqyah Clinic Center in 2013. The information from one ruqyah person on the clinic, Muhammad Nasir, obtained that in principle all the diseases suffered by humans, there is syaithan part in it, because syaithan always try to harm humans in various ways, anytime and anywhere from the right, left, front and rear. Therefore any illness suffered by a person both physical and non-physical illness then the first step that must be done is

${ }^{5}$ https://cahayawahyu.wordpress.com/2012/10/04/terapi-ruq yahterhadap-penyakit-fisik-jiwa-dan-gangguan-jin/, Article under the title Terapi Ruqyah terhadap Penyakit Fisik, Jiwa dan Gangguan Jin oleh Muhammad W. Budiman, Retriver on December 2015. 
treatment with ruqyah as way to avoid, deter and eliminate interference syaithan while medical treatment is just as a supporter. ${ }^{6}$

In Indonesia, ruqyah Syar'iyyah taught by the Prophet Muhammad, it began to boom (popularized) after such time introduced through ruqyah bulk in various areas in early 2003 by a group of organizations, to dissemination through mass media, both electronic and print. With the spread of information about ruqyah Syar'iyyah in Muslim society, then ruqyah Syar'iyyah be a great hope for treatment in accordance with Sunnah of the Prophet Muhammad SAW. So the need for availability of a place or ruqyah clinic and ruqyah person are higher. So many districts in Indonesia predominantly Muslim has ruqyah person and ruqyah Syar'iyyah clinics.

Since ruqyah Syar'iyyah known by the people in Indonesia in 2003, then there are many persons in Riau who learn how to ruqyah so that at the end they actively serve communities request their services for treatment. Indeed, there are clinics provide by them for ruqyah practice. Some ruqyah persons active in serving the community at several districts in Riau are Pekanbaru, Kampar, Pelalawan and Teluk Kuantan.

Based on the problems above, ruqyah Syar'iyyah was not only effective for treating psychiatric disorders and genie but also serves to help physical ailments treat while most people do not know and believe in it. The writer considers very important to examine in depth and explain to what extent Syar'iyyah ruqyah effectiveness in healing of physical disease in Riau province. The discussion will be focused on two formulation of the problem, namely:

\footnotetext{
${ }^{6}$ Adynata, "Penerapan Sunnah Rasulullah SAW.; Ruqyah Syar'iyyah di Surabaya Ruqyah Center dan Pengaruhnya terhadap Pasien” (Research Report, Pekanbaru: UIN Suska Riau, 2013), 66.
}

1. What is ruqyah shar'iyyah method used in Riau Province?

2. What is the effect of ruqyah shar'iyyah in treating physical illness in Riau province?

To answer the formulation of the problem above, the writer conducted field research or qualitative research where the analysis was not based numbers and statistics count but by phenomena of the research object to uncover and understand something behind phenomena unknown.

The data obtained by observation and interviews with ruqyah person and physical illness patients in Riau Province, as well as documentation. Then the data were analyzed by using descriptive method that outlines the facts obtained then linked with the existing theory to answer the issues raised above.

\section{Discussion}

\section{Ruqyah Shar'iyyah Method}

Ruqyah Syar'iyyah methods were practiced by ruqyah person in Riau Province can be categorized into two, namely the manual method and practical methods.

\section{a. The manual Method}

Ruqyah methods manually is a procession ruqyah Syar'iyyah with merely reciting verses of al-Quran and praying maktsurat and praying in ruqyah language understood the meaning. In addition, water is often used as a means of treatment by reciting ruqyah verses then blown and drunk or applied to the patient.

Ruqyah person in Riau who performed manual methods are Ustadzz Aliran, Ustadz Waris in Pekanbaru, Ustadz Syaiful, Ustadz Khaidir and Ustadz Aldin Susilo in Kampar. Ustadz aliran described the methods which he did - in line with other ruqyah person - as follows: ${ }^{7}$

\footnotetext{
${ }^{7}$ Interview with Ust. Aliran on November 14, 2015 at UNRI
} 
First, the preparatory phase for both peruqyah as well as for patients. Ruqyah person let familiarize themselves in obedience to Allah commandments and away from the ban, always read al-Qur' an every day. Before the process ruqyah implemented, both ruqyah person and patients must first let take ablution and prepare a place for ruqyah clean from the pictures of animate beings. Then the patients asked to shut down the entire private parts (aurat), ruqyah person was going to ask some questions about faith and illness. If the patient still believes in shirk or store objects such as amulets, all of it must be disposed of or burned. Then, patient was taught the knowledge of faith, and guided to repent to Allah SWT from all sin he had done by saying astaghfirullahal'adzim and permeates its meaning. If it presents in his hearts various diseases such as resentment, jealousy, conceit, arrogant, low self-esteem, and others that are not justified by Syari'ah, then, it would be guided to cleanse his heart from all diseases. It will nourish deceit syaithan within him. Patient was ordered to sit or lie down and be ready listen ruqyah verses. Ruqyah person normally use gloves to keep in case of a reaction in patient when ruqyah did and needed to be held or touched on the sick then ruqyah person did not directly touch the patient's body.

Second, the process ruqyah Syar'iyyah. Ruqyah begins with the sincere intention for God to carry out Sunnah of the Prophet Muhammad., Followed by reciting taawwudz or praying refuge in Allah SWT from syaithan. Then ruqyah person convey the threat with a language that is understandable to the genie that may be annoying and dwells in patient to leave disturbances, otherwise, it will be recited al-Qur'an verses to force them out of the body of patient. The threat of ruqyah person is sometimes enough to make genie fear and out of patient. But if it did not happen any reaction, then ruqyah person continue reciting al-Qur'an verses. According to Ustadz Aliran that all al-Qur'an verses can be used as a reading ruqyah Syar'iyyah, although there was indeed a recommendation read certain passages based on the Sunnah of the Prophet Muhammad SAW. Therefore, he could practice in ruqyah patien is reading any verses concerned, and he continued to read the previous verses he read well when concerned with other patients or not.

When the verses recited often occurs at the patient as crying without reason, fear, anger, yelling, hitting, felt something move inside the body, sudden pain in certain part of body and others. Toward reaction, ruqyah person will continue to read al-Qur'an verses while touching part of patient's body reacts, both with normal touch by putting the hands or by hitting him as he told jin will be out of patient's body. Ruqyah person sometimes guide the patient if it is able to hold his own body that react and teach to expel jin independently. This way will continue to do so patients feel healing with God's permission, It sometimes one ruqyah session takes half an hour, an hour or two, and even more. If one ruqyah patient had not yet felt healing of illness then proceed with the next ruqyah and it will be done in the same way. In fact, patient often must undergo several times ruqyah to get a complete recovery.

Third, the stages after ruqyah. After ruqyah process is done, the patient is recommended increasing obedience to God by doing sunnah deeds especially by remembrance of God in every situation, and dzikir in morning and afternoon taught by the Prophet SAW. 


\section{b. Practical Methods}

Practical method of doing ruqyah is the development of a manual method as described before. This method detect faster disturbance jin in the body and complete ruqyah process faster. As revealed by Ustadz Febri Albiri ${ }^{8}$ this practical method is called Qur'anic Healing treatment. This method was first introduced by Ustadz Perdana and developed by his student named Nuruddin al-Indonisiy. This method is also practiced by Ustadz Albiri.

Describing from ruqyah practical method of Qur'anic Healing can be explained as follows:

\section{Muqaddimah of Ruqyah}

Before doing ruqyah, let the patient in a condition ready for ruqyah. At least there are some steps need to be done to start this therapy.

\section{a). Place condition}

1. Ruqyah place should be clean, cool and quiet in order al-Qur 'an trill can seep into qalbu patients.

2. Clean the place from all objects which is sacred antidote magic amulets, statues and paintings animate included photo.

3. Read Ayat Kursi to fortify place and ask refuge in Allah, also give perfume room.

a. Preparation for patient: Here are things must be done before therapy:

1. Setting up conditions to the patient's life in a way led him to be strong release all forms of resentment and disappointment in past.

2. Patient should take

${ }^{8}$ Ustadz Febri Albiri is ruqyah person at al-Syifa clinic of Taluk Kuantan-Kuantan Singingi distric of Riau Province. Interview done on October 2015. ablution in order physical and spiritual relax.

3. Ask to break free and home from the sacred objects and amulets antidote and back to Allah.

4. Inviting patients repent.

5. Guide patient to pray and seek refuge and strength in God.

6. Directed patient to relax and listen with humility ruqyah verses to be recited.

b. Preparation For Ruqyah Person

1. Take ablution

2. If the problem is severe, do Shalat Mutlak 4 raka'at seek refuge to Allah.

3. Read self fortification praying and fortify location (with Ayat Kursi).

4. Preparing equipment/means for ruqyah.

5. Identifying the disease, distinguish medical or magic, and deduce type of therapy and do therapy.

c. Starting Ruqyah

There are some things need to be done before starting ruqyah or perform ruqyah independently (self). They are to prepare the place, psychologically and physically, courtesy in praying to God, and destroyed before hand all the objects contain shirk.

Procedures start ruqyah independently (self) or ruqyah other person, if an emergency condition is as follows take ablution, do mutlak praying, reciting ta'awudz, Basmalah, 
istighfar and Shalawat Nabi, pray for strength to God, do ruqyah.

\section{b). Tazkiyyah and Counseling}

After completing ruqyah preparation, the next step finds more information from the patient. This counseling aims to explore more information that will help us to accompany or guide patients toward healing approves. It is begun by positioning self as a spiritual doctor needed by Patient, having empathy to patients. Welcomes soul of patient hear all complaints and backgrounds or causes pain he knew.

Then, asking patient personally at which point or pain in his body and whenever the pain was attacked as information to find solutions or ways of treatment. Digging deeply and tell the patient are about the importance of honesty this information, tell him this is not a disgrace and promise to keep it quiet and willing to pledge his soul about his mistakes. Then answered all the problems with tausiyyah and tazkiyyah method, take 10 to 30 minutes to explain to patients about the meaning Ruqyah Syar'iyyah and of true healing asking to God to free themselves from various forms of shirk.

Things that need to be asked when counseling is the involvement of patients with proceedings shirk such as maintaining talisman, heritage, inner power, mysticism and similar things, and deeds heresy might do, then patient is guided to repent.

To be able to do counseling at least a therapist must know and enlighten patients on ways jin into human body and the characteristics of a shaman to assist patients in analyzing the causes of disease.

\section{c). Al-Qur'an Treatment}

The next step is recited ruqyah verses on ear with tartil. Ruqyah verses meant a standard verse that should be read out in every ruqyah of disturbance $j$ in or magic. This verse was read in every ruqyah procession by holding patient's head or a sore spot with touch or read in his ear.

The Standard verses based on the Hadith of the Prophet Muhammad is surah al-Fatihah, 4 verses beginning of Surah al-Baqarah: 1-4; mid of surah al-Baqarah: 163-164, Ayat Kursi (al-Baqarah: 255); 3 verses last of surah al-Baqarah: 284-286, surah Ali-Imran: 18, al-A'raf: 5456, al-Mukminun: 116-118, al-Jin: 3, al-Saffat: 1-10, al-Hashr: 22-24, al-Ikhlas, al-Falaq and an-Nass. On progress, these standards ruqyah verses are added or complemented by scholars who are competent in ruqyah. They are Surah al-Fatihah, al-Baqarah: 1-5, 102-103, 163-164, 285-286; Ali-Imran: 18-19, al-A'raf : 54-56, 117-122, Yunus :81-82, Taha: 69, al-Mu'minin: 115-118, al-Saffat: 1-10, al-Ahqaf: 29-32, al- Rahman: 33-36, al-Hashr: 21-24, al-Jin:1-9, alIkhlas, al-Falaq and an-Nass.

\section{d). Handle Reaction}

If the patient starts to react, the first thing to do is not to panic. Stay calm and do not be afraid, fear is only to Allah in order all His creatures afraid to us. The techniques to handle patient reacts based on techniques of Quranic Healing development are as 
follows:

1. Touch technique, while reading "Bismillah ( $7 \mathrm{x})$ a'uzubillahiwa qudratihi min syarri ma wa ajidu uhazir".

2. Pat technique, which is done after showing reaction to expel jin inside patient's body.

3. Pressure technique, which is pressing on a specific body part by read:

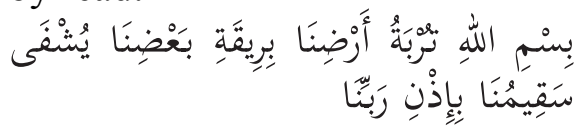

"In the name of Allah, this is the land of our earth, mixed with saliva of us, with it be healed sick among us, with the permission of our Lord".

This technique serves to destroy, torture, and detect jin.

4. Sweep technique that is rubbed on the affected part by hand after reading ruqyah verses and blowing hand to be rubbed.

5. Blowing technique is to read ruqyah verses then blown into sick part with intent to burn, heal or destroy the magic.

\section{e). Closing}

1. Completing the Rest of the Magic

Once the procession is completed, patients experience severe vomiting and felt weak, ruqyah person check the existence of jin, whether they are in the patient's body or already out. The trick is to look at the signs or re-direct scanning by reading a certain verse. For example, by placing a hand on top of his head and read surah
Hud verse 56:

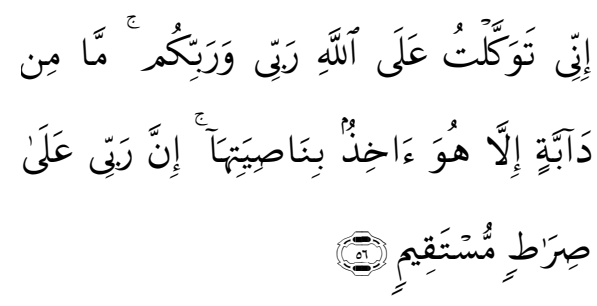

Indeed I have put my trust in Allah. My lord and your lord. There is no living being but he holds it by its forelock. Indeed my Lord is on a straight path.

Besides, it also can be read surah al-Baqarah 148 to summon jin back if it has not been out yet or still around there, namely:

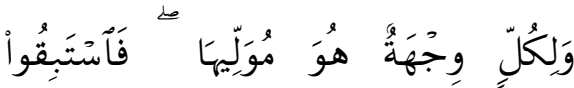

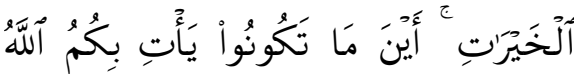

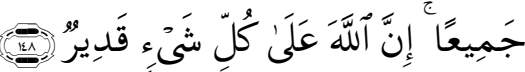

For each [religious following] is a direction toward which it faces. So race to [all that is] good. Wherever you may be, Allah will bring you forth [for judgement] all together. Indeed, Allah is over all things competent.

If the verses above have been read repeatedly but there is no reaction. Therefore, saying Alhamdulillah and suggest the patient is to prostration gratitude because God willing genie has been already out. And God knows better about this.

Then, the task of ruqyah person is to keep jin not come back. Before doing this, ruqyah person should reassure patients 
about what he felt. If the patient answered "fresh" and conditions such normal without pain (except former hospital massage or normal pressure in the body, and also the pain felt weak in the body), then God willing, this phase is completed. The next task of ruqyah person is to advise the patient.

\section{Attractive Jin}

There is usually heat or cold heat or tingling, severe or mild twitch in the wrist, hands and feet as well as wrist in post-ruqyah. It should not be allowed and must be directly addressed to complete. The way is by reading surah alMukminun: 115.

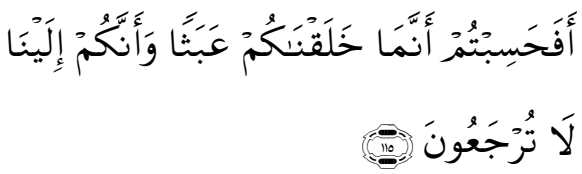

Then did you think that we created you uselessly and that to Us you would not be returned?"

Then, he is blown into the hands and pulled out toe or hand while reading " "La Haula walaa quwata illa billahil aliyhil adziim". It is made two or three times until the pain disappeared completely. Once again do not consider trivial with remnants of this illness, because it indicates the existence of jin. If there is just one jin did not come out, then he will be a door to get back into patient's body.

If proved difficult magic is lost or is not completed. Stop ruqyah as this will only spend time, but recommend patient go home and arm with ruqyah techniques independently. After the disturbance jin was lost then ruqyah person is to instill tauhid values in patient as defence of jin or syaithan.

\section{Treatment of Medical Disease Patients by Ruqyah Syar 'iyyah}

In this section, it will describe the data of patients suffering medical illness that consists of information about the history of physical ailments suffered by patients, medical treatment efforts that have been made and influence of ruqyah Syar'iyyah in healing process. Data will be presented by taking one sample of each type of illness.

Patient 1: acute skin diseases accompanied by headache and total hair loss

This disease suffered by a housewife aged 62 years. This disease early experienced by patients on 2010 in Tanjung Pinang city of Riau Islands Province. Where at first She felt fatigue on left hand, then became so weak so that anything held was fall. When asked the doctor, she just "exhausted." A week later, the whole body feels sore, and a sense of fatigue creeping into left hands, accompanied by intense itching and spread to the right, then go to a masseuse and said " you were tasapo". ${ }^{9}$ Further, her skin all over the body peeled off, the entire hair loss and physical condition is getting weaker. The patient went to specialist in Tanjung Pinang and did examination but did not find the disease

\footnotetext{
${ }^{9}$ Tasapo is term used for person disorder jin, either in the form of
} magic brought by the shaman and jin desires. 
in the patient and doctor recommended to conduct investigation into the Naval Hospital in Tanjung Pinang. The doctor who examined the patient also did not find any particular disease. He suggested going to "orang pintar". Therefore, by family were taken for treatment to various areas in Riau, Palembang and West Sumatra, but have not received healing, and finally brought treatment to Specialist at Eka Hospital Pekanbaru for examination tendons and bones. But, doctors also did not find the type of illness but he was advised to do surgery. Then her husband asked the doctor, "what are you reason operated on my wife, while you said disoriented about my wife illness." Doctor said, "We just try first." Then, her husband said "my wife is not like a machine, you do not know what my wife illness before, on what reason you do operation?" Finally, based on suggestion from two family members, then the patient is treated by ruqyah by Ustadz Aliran are located in Pekanbaru as much as five times. Patients have often done ruqyah in Tanjung Pinang before by Ustadz Fajar, but had not completed yet.

In the first ruqyah on 2012, the patient underwent a ruqyah procession for 1 hour and felt significant change in physical and non-physical and felt hungry, remember the time of doing praying, sleep well even though it has been years patients cannot sleep well, can perform praying by sitting whereas she previously only able to pray lying down, itchy all over the body was missing and whitened skin starting to show signs of recovery. Furthermore, patients continued ruqyah process up to four times and get healing almost perfect except for the skin on right hand fingers which still looks white.
Patient 2: Ulcer disease accompanied by headache

The disease is experienced by a housewife 39 years old in Kubang village Kampar district. This disease experienced by patients on 11 Ramadan 1436/2015 in which patients felt abdominal pain and headache and heart beat. This disease begins when she woke up for sahur, he felt dizzy, sweating out wet clothes, fatigue, heart beat. The next day, she saw the doctor and he said is heartburn because stomach acid. She were given medicine so that she can perform tarawih praying for two nights but headache and heartburn still sore but it's been slightly reduced. Three days later, she saw another doctor and claimed the same disease with a doctor earlier and given the same medicine. Four days before Lebaran 1436 $\mathrm{H}$, she felt a limp hand and saw the third doctor and states as well ulcer pain. Then after Lebaran, she went to specialist at RSUD Pekanbaru hospitals. Here, patient was stated experiencing Chronic ulcer disease and also given heartburn medication, but also no change. A week later, she saw cardiologist and stated there are no heart diseases. Whereas, she had brown eyes could not sleep night and day. Then, based on the suggestion from a neighbor who had been undergoing ruqyah treatment, in case of headaches, ulcers, eye could not sleep, heartbeat, home is not at home, feeling fear but do not know what fear, patients treated ruqyah to Ustadz Aliran in Pekanbaru two week later.

First ruqyah occurred approximately 30 minutes along with other ruqyah patients. Firstly, patients feel scared for no reason, and feel heat both sides of the body to the head. Then the patient is guided to istighfar and ruqyah process 
carried out to completion. After the first ruqyah, patients feel a change in the form of convenience, reduction in abdominal pain stabs and dizziness are also reduced, and the fear is gone and unable to sleep.

Secondly, ruqyah performed 4 days after the first ruqyah, it happened lonely does not coincide with other patients by Ustadz Aliran, about 30 minutes. When the process ruqyah, patients was crying that cannot be controlled, without cause and belching. Changes patients feel is heartburn and head is gone, but Ustadz Aliran suggested ruqyah continually for a third to make sure the patient is completely cured. A week later do ruqyah third. Although the patient when it is no longer feel the heartburn and headaches, but when the procession ruqyah, she cried more powerful than the second ruqyah. After conducting the third ruqyah patients experience heartburn and head have disappeared altogether.

\section{Patient 3: Headaches hereditary}

The disease is experienced by a housewife who was 25 years old in the area of Kampar. First, she felt headaches are often experienced only pain he deriv e d from her parents so that she feel $\mathrm{s}$ is common. This illness had begun for two years before getting married in March 2014. She often felt even never had headaches for 8 hours without stopp ing. Frequency arrival of this headache is not regularly, at least once a week occur especially if there is a problem and also occur up to four times a week. It is not migraine (headaches) but throughout the head.

Efforts done by the patient to cure the disease before ruqyah therapy went to midwife and saw the doctor, but she were not ignore the pain because it was just an ordinary headache derived from her parents. Midwife or doctor said it was only suffering normally headache. After married, she experienced nightmares. On the advice of her murabbi, she underwent ruqyah therap y. For the first time, she were undergoi $\mathrm{ng}$ treatment at ruqyah clinic and cupping in Pekanbaru for one and a half ho ur. When the process of ruqyah, she felt a tremendous headache like pressed strongly by ruqyah person. Whereas, it w a s only by attaching a hand above head as corroborated by her husband testimony. When azan Maghrib reverb, ruqya $h$ person discontinue therapy, mean i ng that therapy was not finished and after that she did not continue therapy at the clinic. Amended she felt hea $\mathrm{d}$ ache and emotions grow increasingly out of control after the first ruqyah.

Two weeks later, she came to Ustadz Aliran to do ruqyah and through the process of ruqyah for about 30 minutes. After ruqyah, patients experience fewer headaches, and felt comfortable until next days when it comes menstruation, she felt pain in the chest with palpitations, but when the data is obtained, the patient has not recovered completely, the patient continued the next ruqyah.

\section{Patient 4: Desmoplastic Cancer}

Desmoplastic small cell tumor is cancer of soft tissue of rare type that typically develops in the abdomen. Desmoplastic small cell tumor most commonly affects men and boys, though this tumor can also occur at any age and affects women. This aggressive cancer often appears in the form of a group of tumors in tissue (peritoneum) that lines inside of the abdomen and 
pelvis. They quickly spread to other structures in abdomen. Desmoplastic small cell tumor is a type of soft tissue sarcoma. ${ }^{10}$

Patients suffering Desmoplastic cancer is man 39 years old. He has suffered from this disease since August 2014. It was initially only a small bump in the lower back to the right that did not bring the pain, then he saw to the Specialist Doctors at Eka Hospital Pekanbaru and Doctor did not find this kind of pain. A week later, he saw Surgeon at Awal Bros Hospital in Pekanbaru, but it also has not been found a diagnosis. But the longer lump growing. After the cancer enlarges then the doctor can diagnose the disease: cancer Desmoplastic. On June 16, 2015, patients treated with surgeons and surgery so that the cancer cells in the lower back can be dispensed which weighs around $3.5 \mathrm{~kg}$. Likewise, the patient was after surgery feeling pain when previously. A month later cancer return to normal and even larger, then he routinely perform control to surgeons and did vacuuming liquids cancer cells. Patient is referred to surgeons at the same Hospital, then the doctor said too late to bring patient to him, then the action can be done is only chemotherapy.

On October 23, 2015 patients underwent treatment with ruqyah Syar'iyyah way for two hours for the first time conducted by Ustadz Aliran. Patient feel whole pain goes away after ruqyah, calm the mind, can sleep soundly and weakness due to lack of nutritional food. The patients then continued ruqyah second, he did not feel physically change significantly except for feeling more calm,

\footnotetext{
${ }^{10}$ see http://www.sehatfresh.com/tumor-desmoplastic/, article under the title "Tumor Desmoplastic", by Doctor Sehat Fresh team. Retrieved December 2015.
}

comfortable and no longer slurred. Once on the initiative of his wife, patients discontinued ruqyah third by reason of the patient's condition deteriorated and was admitted in the hospital so that he pass away on Thursday, November 26, 2015.

\section{Patient 5: Tonsils}

Tonsil is experienced by a child of four years in Taluk Kuantan. His tonsil red and fester so often makes him a fever and he was taken for treatment to a General Practitioner. According to doctors, fever is often experienced by patient is caused by the tonsil, then he was given medication, but the pain experienced no changes. Furthermore Ustadz Febri Albiri did ruqyah by reciting intended, read a praying for healing and rubbed the tonsils of patients while reading "Bismillah, Allahuakbar." After that, fever and pain gone, and the next day the swelling in the neck of the patient was also missing.

Patient 6: Toothache

Dental pain experienced by two people, housewife and children Taluk Kuantan. Both of these patients did not go to the doctor, but they did ruqyah by a husband and father both by way of reciting verses ruqyah near toothache and bring mobile phone reciting murattal al-Qur'an until they feel lost.

\section{Patient 7: Sore eyes}

Patients suffered from sore eyes 24 years old that live in Ujung Batu Rokan Hulu. Sore eye came suddenly at $8 \mathrm{pm}$, in which the patient feels there is little sand in large quantities into eyes causing sore made patient was not able to open his eyes. Initially, he thought in a span of 1 
to 2 hours, his pain will go away by itself because he believes his sickness caused by laser beam welding eyes see iron in the afternoon a few hours before he felt sore eye.

After 4 hours elapsed sore eye that is felt is getting worse, he did treatment to Ustadz Arif. Ruqyah did as many as three sessions, where one session lasts for 15 minutes. In the first session, patient began to be able to open her eyes and sore has begun to decrease. The second and third sessions were diminishing sore but not yet complete. Ruqyah person believes that the patient did not experience interference from jin but purely physical illness, because when ruqyah verses recited as many as three sessions there was no jin disorder symptoms in patient. Ustadz Arif continue with cupping treatment and provide herbal medicines so patients recover completely before advent of dawn.

\section{Patient 8: Typhoid}

Patients had typhoid is a man who was about 42 years old. Typhoid suffered by patients since 2013 when he felt a high fever and heartburn. Then he went to Zahrah Hospitl in Ujung Batu, continued to Ibn Sina Hospital and Awal Bros Hospital in Pekanbaru. Some of Internal Medicine stated that patient was suffering from typhus, and one Specialist Doctors declared typhus accompanied by swelling of intestines. The action taken by doctors is hospitalized with giving medicines and infusion. When in handling at hospital, patients feel diminished, but after being in the house, pain increases were probably caused when at home simply by taking medications alone without infusion.

Then in June 2015, the patient underwent Syar'iyyah ruqyah therapy for the first time with Ustadz Herman Santoso in Ujung Batu for one hour. Amended felt after ruqyah are high fever and headache reduced. Then the patient is taught ruqyah independently at home, and it done for a week after performing subuh prying for about 30 minutes. Ruqyah reading is Surah al-Fatihah, ayat kursi, surat al-Ikhlas, al-Falaq and al-Nas. Then it breathed into his hands and holding sore body part. After a week had passed, the patient did not feel healing he came to Ustadz Herman Santoso to ruqyah the second time. In the second ruqyah, patients experienced severe vomiting and feel the body heat is lost as well as headaches and stomach heat is lost altogether. Furthermore, the patient was no longer proceed riqyah with Ustadz Herman Santoso, but he still do ruqyah independently at home a few days later.

\section{Patient 9: HIV}

Data on HIV disease suffered by the patient cannot be obtained directly from the patient, but through ruqyah person Ustadz Herman Santoso who treat it. This is done because patients were not willing to be interviewed either in person or via telephone. HIV disease suffered by patients transmitted by her husband who had died in 2012 due to HIV disease, as well as one of five-year-old son was also infected with the same disease. HIV disease suffered by patient and her son is based on the claim Doctor at Ibn Sina Hospital Pekanbaru.

In September 2015, patient decided to undergo therapy ruqyah Syar'iyyah with Ustadz Herman Santoso in Ujung Batu. The beginning of ruqyah process, the patient was told to do istighfar as much as 100 times as a form of repentance to God with all sincerity. Then ruqyah 
person recited ruqyah verses by reciting al-Fatihah three times, causing a reaction in the patient in severe vomiting while "jengking-jengking." ${ }^{11}$ Likewise, his son severe vomiting occurs as people who suffocated as people drawn from the top. The first ruqyah lasted about an hour. After the first ruqyah, patients feel change were that they can sleep soundly, whereas before they used to wake up at midnight and cannot sleep anymore. Two days later Ustadz Herman Santoso provide water concoction made from Daun Tapak Liman and Ginger ${ }^{12} \mathrm{th}$ at ruqyah with standards verses and surh al-Hasyar: 21, to be taken by patient and his son, and the concoction is drunk three times before continuing second ruqyah process. Reaction of these drinks is the patient vomiting even without re $\mathrm{c}$ ited ruqyah verses and fever higher than before so nearly the patient wants to cancel the treatment being unable to withst a nd fever experienced, but Ustadz He r man Santoso provide an understanding that the reaction of the herb is like that, and if the fever has stopped, then God willing, the patient is cured.

The second ruqyah performed about one week after the first ruqyah, which lasted about an hour. The reaction was vomiting patients but not as severe vomiting in the first ruqyah, and will no longer be given herb Tapak Liman and Ginger because the patient's condition was at the second ruqyah is good enough. A perceived change significantly

\footnotetext{
${ }^{11}$ Jengking-jengking is Javanese language, which means upside. These patients when did ruqyah severe vomiting as the upsidedown because of the strength of vomit out of his mouth.

${ }^{12}$ Ustadz Herman Santoso provide Tapak Liman herb and Ginger on the advice of his friend Kang Hari al-Banjary, a practitioner Ruqyah in Koto Bogor specifically do ruqyah for HIV treatment. He says that leaves Tapak Liman serves to kill the HIV virus and Ginger is hot, then recited ruqyah verses then drunk by the patient.
}

by hearing has begun to improve, and the eye was already getting light. Then next three days followed by a third ruqyah and no reaction to anything though ruqyah conducted for one hour. After that, the patient was again granted drink Tapak Liman Herbal and ginger. It turned out that patients were no longer have a fever as before. One week later, the patient returned to health check at Ibnu Sina Hospital Pekanbaru and the results Doctors declared her HIV negative.

Patient 10: Mad and drugs addicted

Mad and drugs addicted include physical illness because both are damage to the nerves of brain. According to Ustadz Andi who lives in Ujung Batu, he had often treat patients suffering from two types of this disease by means of ruqyah Syar 'iyyah and many patients can be cured with the permission of Allah.

\section{Analysis}

\section{Methods of Ruqyah}

Based on the information from ruqyah person and direct observation on riqyah process in Riau province, in this case took samples at four districts/cities - Pekanbaru, Kuantan Singingi, Kampar and Rokan Hulu. It found two methods ruqyah, manual method and practical methods of Qur'anic Healing.

The manual method is done by exemplified the Prophet Muhammad SAW and his companions, both in terms of detection of disease, treatment of patients if there is a physical reaction of reading ruqyah and completion of ruqyah process. Disease detection is done by merely reciting ruqyah verses and pays attention to the reaction of the patient or the emergence of pain in patient's body, or feels something is moving, or patient crying for no reason, or trance and others, it is ascertained that patient is in disorder syaithan. 
Handling patients who react only to the extent exemplified the Prophet Muhammad SAW that lay hands on the sick limb and read ruqyah verses and praying. It sometimes by hitting slowly and told the jin that was permeated to exit. If the patient does not feel the change then ruqyah continue until God gives healing.

The stage of completion, if the patient is already feeling that he experienced pain had disappeared altogether then ruqyah person will repeat reading al-Qur'an verses to ascertain whether there is interference remaining. If there is ruqyah should be continued or done on other occasions.

Thus, all ruqyah way is done manually can be believed to be based on Hadits the Prophet Muhammad SAW and do not cross the boundaries are exemplified. It is no doubt that this method in accordance with al-Sunnah.

Ruqyah practical Qur'anic Healing method basically has similarities with manual ruqyah method as described above, It is just practical Quranic Healing method undertake development of techniques ruqyah in five ways: a) touch, b) pat, c) pressure, d) swabs, and e) blowing. It will explain one by one:

a. How to Touch

This way find in hadits of the Prophet Muhammad SAW narrated by Muslim, Nasa'i, Thabrani and others, as follows:

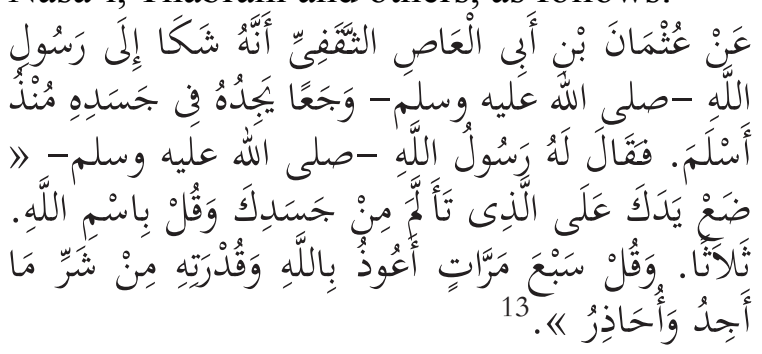

"From Utsman ibn Abi al'Ash al-Tsaqafy that he told to the Prophet Muhammad about a disease suffered since he converted to Islam. Then the Prophet said to him: "Put your hand on your body

\footnotetext{
${ }^{13} \mathrm{Abu}$ al-Husain Muslim bin al-Hajjaj bin Muslim al-Qusyairy al-Nisabury, Sahih Muslim, Juz 7 (Beirut: Dar al-Jil + Dar alAfaq al-Jadidah, t.th), 20.
}

that feels pain, then recite Bismillah three times, then read seven times: A'udzu billahi wa qudratihi min Syarri ma ajidu wa uhadzir." (I seek refuge in Allah and his might from illness I suffer and I worry about)".

Hadits above based words narrated by Imam Muslim in which the Prophet asked Utsman bin Abi al-'Ash al-Tsaqafy to put his hands on the sick part of body. This means that Utsman was actually touching hands on the sick, although he did not mention touch. However, based on the hadits of Thabrani in his book al-Mu'jam al-Kabir and al-Hakim, the Prophet ordered him to rubbed the sick limb with lafaz "امسح", As his saying:

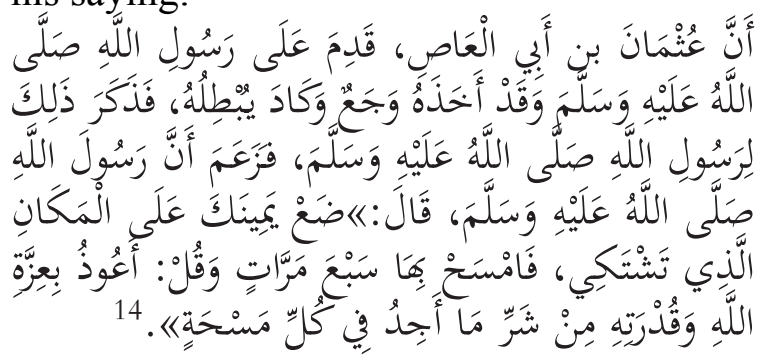

"Trully Utsman bin Abi al>Ash came to the Prophet when he was suffering a disease that almost destroy him, and he told the Prophet, then he advocated by saying, "Put your right hand on the place where you complain about it, then sweep up as many as seven $A$ time and say A'uzu bi'izzatillah wa qudratihi min Syarri ma ajidu on each sweep" (HR. Thabrani).

Based on both hadits above, it can be concluded that in doing ruqyah touch technique is a technique of sunnah that is pressed his right hand on the limb pain and then leave without doing other movements while reading al-Qur'an verses.

\footnotetext{
${ }^{14}$ Sulaiman bin Ahmad al-Thabrani Abu Qasim, al-Du'a, Juz 1 (Beirut: Dar al-Kutub al-Ilmiyah, 1413), 344.
} 
b. Pat

Ruqyah person used this technique postulated to hadits narrated by al-Thabrani in the book of al-Mu'jam al-Kabir:

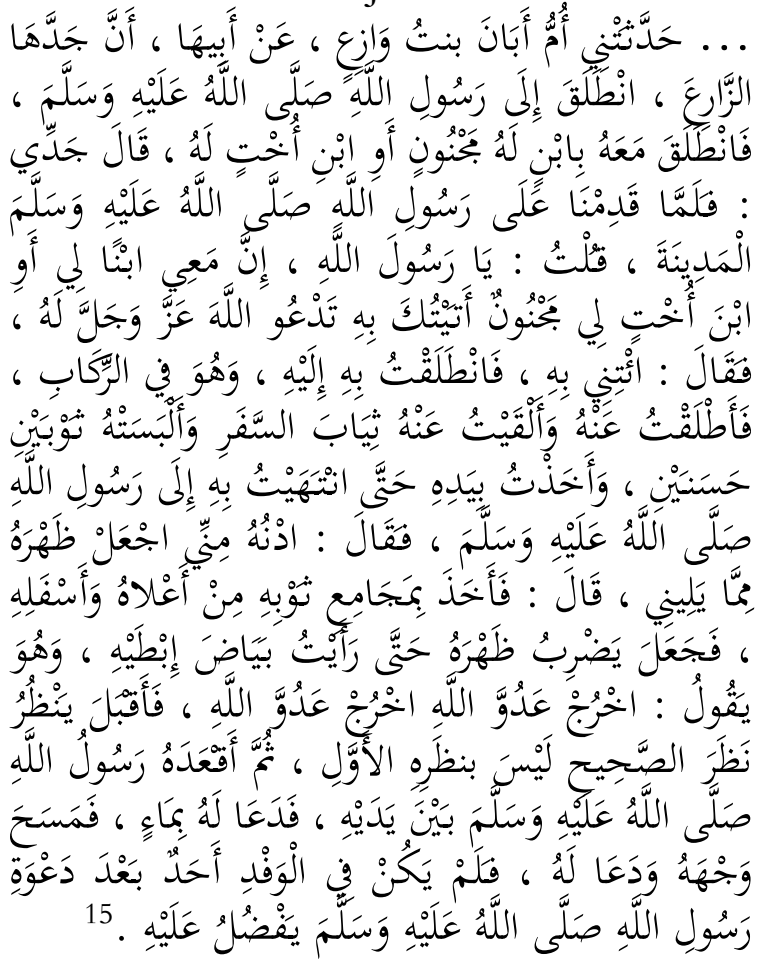

“...Ummu Aban bintu Wazi 'told me of his Father that his grandfather alZari' came to the Prophet Muhammad carrying a boy or a girl. My grandfather recounted: "When we came to the Prophet Muhammad in Medina, I said:" O Messenger of Allah, verily I bring a boy or a girl I was mad ask that you pray for his recovery to God Almighty, he said," Bring him/her here, "then I took him/ her on vehicle and release straps, then I remove the clothes his journey, and used him a pair of beautiful clothes, I took him to the Prophet so when I've got him, he said," draw near him to me and put her back in front of me, "then he holds the tip and base fabric and pat the child's back so it looks white armpits, while he said, "get out, O enemy of God! Come out the

\footnotetext{
${ }^{15}$ Sulaiman bin Ahmad bin Ayub bin Mathir al-Lakhmiy alSyamiy Abu al-Qasim al-Tabrani, al-Mu'jam al-Kabir, Juz 5 (Kairo: Maktabah Ibnu Taimiyah, t.th), 234.
}

enemy of God!" Then the child can see back normally, like the usual. Prophet Muhammad saw sit the child in front of and prayed for him and rubbed his face (HR. al-Thabrani)

Al-Shaikh Ali hasyisy in his book Silsilah al-hadits al-Wahiyah ${ }^{16}$ mentioned the comments of Ibnu Hajar al-Atsqalani supported al-Mizzy explanation as follows:

1. At that lines, there is solitude of perawi that Mathir bin 'Abd al-Rahman alA'naq receives from Umm Aban as has been described by al-Zahabi, al-Mizzy, Ibnu Hajar al-Atsqalani and al-Haitsami. Ibn Hajar mentioned in his book Syarh alNukhbah Nau' 40 :

$$
\text { و بحهول إنمي الراوي وانفرد راو واحد بالرواية عنه فه }
$$

"If it is mentioned the name of a narrator and occurs solitude student who narrated Hadith from him that he was a majhul al-'ain (unknown person)."

2. After tracking it is known that none of Ulama al-Jarh wa al-Ta'dil which perform tsiqah Umm Aban.

3. It can be concluded that Ummu Aban is majhul 'ain and none Ulama al-Jarh wa al-Ta'dil stated tsiqah. Therefore, Hadits tells about the story cannot be accepted, as well as al-Iraqy assess in his Alfiah that hadits is mardud or rejected and should not be istinbath.

It found many Muslims make hadits above as a postulate to perform ruqyah by means a pat or blow, but it is bad istinbath because it is based on weak postulte. They treat foolishly and assume that many diseases are caused by

${ }^{16}$ Al-Syaikh Aliy Hasyisy, Silsilah al-Ahadis al-Wahiyah, Juz 1 (Maktabah Syamilah), 200. 
disorders jin and the most useful way is to pat or blow that hurt people with a reason hurt genie possessed. Such acts are never done by any of the companions. Therefore, it is a new case that trumps up never done by Prophet Muhammad and his companions.

Dasman $\mathrm{John}^{17}$ gives an opinion that pat or blow techniques used in an ruqyah unauthorized said to be a ruqyah Syar'iyyah method derived from Sunnah of the Prophet Muhammad because there is no Sahih hadits which can be used as a proposition. According to writer this method let kept away from performing ruqyah Syar'iyyah. By the reason it is not only because there is no maqbul Hadits that can be used as proposition but it can out of ruqyah substance itself in the form of incantation or readings of al-Qur'an verses and sunnah praying. It may be that includes how syaithan distanced ruqyah person of readings ruqyah itself so spend a longer time and can make ruqyah person bored.

\section{c. Pressure}

Pressure technique is a way of ruqyah by reciting al-Qur'an verses and then pressing the sick body. They postulate in using this method to hadith narrated by Bukhari and Muslim.

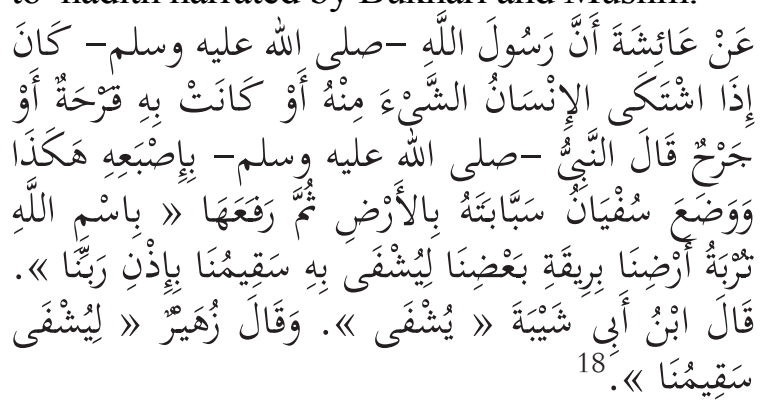

"From 'Aisyah when someone told his suffered an illness or affected by scabies

\footnotetext{
${ }^{17}$ Dasman Yahya is doctor of alumni University of Medina in Field of Hadits particularly al-Jarh wa al-ta'dil and now a lecturer at Ushuluddin Faculty of UIN Suska Riau.

${ }^{18} \mathrm{Abu}$ al-Husain Muslim bin al-Hajjaj bin Muslim al-Qusyairy al-Nisabury, Juz 11, 191.
}

or injury to the Prophet Muhammad, the Prophet say while moving his fingers like this - Sufyan put his finger to the ground, then picked it up - Bismillah turbatu ardhina biriqati ba'dhina liyusyfa bihi saqimuna bi izni Rabbina. "(in the name of Allah, with the dust of our earth, with most of our saliva, may be healed our diseases with the permission of our Lord). Ibnu Abi Abi Shaibah said; ruqyah reads "Yusyfa". And Zuhair said; "Liyusyfa saqimuna."

Imam Nawawi explains, Jumhur Ulama said that the meaning of our land in hadits is a lump of soil, some have argued specialized Madinah land because its blessing. The meaning of saliva here, he took his own spit with his pointer finger and then put it on the land so that there is soil attached and then rubbed into the wounded or sick as he uttered those words. ${ }^{19}$

In Hadits above, the Prophet did that way to treat ulcers and wounds usual, as understood from the words "qarhah" and "Jarh". The way he did by wipe as understood from word "mash", instead of pressing. According to writer, pressure technique was not found Hadits can be used as a proposition. So let abandoned but merely pressed a hand to part of patient's body that is sick and is done by reading ruqyah verses then wipe to the ground while reading the words mentioned in the hadits Bukhari and Muslims above.

d. Rub

They postulated by hadits narrated by Bukhari as follows:

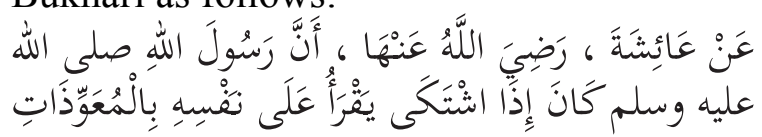

\footnotetext{
${ }^{19} \mathrm{Abu}$ Zakariya Yahya bin Syarif bin al-Nawawiy Murray, alMinhaj Sharh Saheeh Muslim ibn al-Hajjaj, 2nd Edt, the Section 7 (Beirut: Dar al-Turath ihyak al-'Araby, 1392), 335
} 


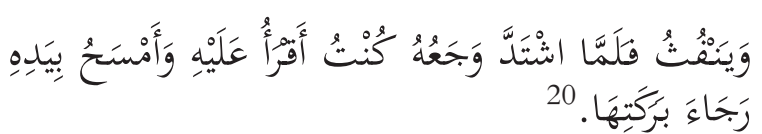

"From "Aisyah RA that when the Prophet was suffering from sore eyes for himself, then he blows. And when the pain severe then I read it to him and then he rubbed by using his hands to expect His blessing" (HR. Bukhari).

In hadits above mentioned when he severely ill, then Aisyah recited alMuawwizat into hands of the Prophet Muhammad and rubbed - by using word "amsah « which means «I am who rubbed». So rub technique is consistent with al-Sunnah.

e. Gust

They postulated by hadits narrated Ahmad of Ya'la bin Murrah as follows: where Ya'la bin Murh ra, during a joint safar with Prophet allugale he saw a mother who was sitting with her baby. The woman begged Rasulullah SAW to treat her baby disease is often recurrent, and the Prophet said; "Give the baby to me "Then she put the baby and the Prophet allugate open his mouth and opened baby mouth, then gust into it three times and say:

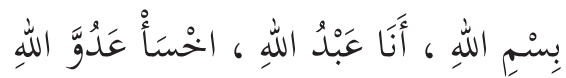

"Bismillah, I am the servant of God, be off with you O enemy of God!"’21

Based on this hadits, it is clear that the Prophet Gust the baby's mouth and blowing technique is consistent with al-Sunnah.

\footnotetext{
${ }^{20}$ Muhammad bin Ismail bin Ibrahim bin al-Mughirah alBukhari, al-Jami' al-Shahih (Kairo: Dar al-Sya'b, 1987), $1^{\text {st }}$ Edt, Juz 7, p. 233

${ }^{21}$ Ahmad bin Hanbal Abu Abdillah al-Syaibani, Musnad al-Imam Ahmad bin Hanbal, Juz 3 (Kairo: Muassasah Qordova, t.th), 170.
}

\section{Effectiveness Ruqyah Syar'iyyah in Healing of Physical Disease}

Based on the temporal changes experienced by patients with physical diseases when being treated by ruqyah, in which ten patients with various physical ailments had previously been treated by medical means, but did not get relief, and then with ruqyah they recover without medical drugs, showed that ruqyah Syar'iyyah has a significant effect in curing various physical illnesses. As many people who believe Syar'iyyah ruqyah just to treat jin disorders and psychiatric illnesses can be uncontested. In fact, according to some ruqyah person stated that any illness suffered by a person, the first and main treatment is by ruqyah Syar'iyyah while medical treatment is only a supporting role.

This is supported by proposition of al-Qur'an and al-Sunnah, such the word of God in surah alIsra' verse 82

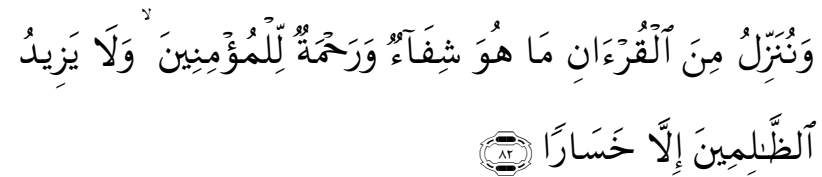

"And We send down of the Qur'an that which is healing and mercy for the believers, but it does not increase the wrongdoers except in loss."

The word of "Syifa" in verse above means bidder or medicine, which is mentioned in a general, the meaning can mean a cure for liver disease or psychiatric and can also mean medicine physical ailments, both physical ailments caused by disorders $j i n$ nor a purely physical symptoms.

Likewise Hadith of the Prophet Muhammad that has been listed previously mentioned that he and his companions made ruqyah Syar'iyyah as a way to treat physical illnesses such as treating scorpion bites, fever suffer by children, minor cuts or wounds festering, insanity. According to one active ruqyah person treat two types of diseases that is crazy and addicted to drugs in Ujung Batu Rokan Hulu, Ustadz Andi insists two diseases are included into the kind of physical 
illness, because it happened to a madman and drug addiction is a breakdown nerves of the brain that are a part of human physical.

Logically, the function of al-Qur'an as a cure for physical ailments is very logical and supported by research scientists. A psychiatrist doctor al-Qadhi conduct research on Large Clinic at Florida United States has ever proved that only by listening to readings al-Qur'an verses, a good Muslim who could speak Arabic or not, it can feel the changes as follows:

a. Physiological enormous

b. Decreased depression, sadness

c. Obtain peace of mind

d. Ward off various diseases. (This is a common effect of which is felt by people who became research object).

Al-Qadi research is supported by latest electronic equipment to detect blood pressure, heart rate, muscle endurance and skin resistance to electricity flow. From the results of trial, he found reading al-Qur'an has great influence up to $97 \%$ in delivery of mental tranquility and healing diseases. ${ }^{22}$

According to one ruqyah person live in Pekanbaru, Ustadz Aliran, there are three types of jin based on hadits of the Prophet SAW, namely (1) jin without existence, only in form of gas or wind include in this category is winged and flying in the air, (2) jin-type animals such as jin of snakes, tigers, monkeys, bats, scorpions, rats, dogs and other dirty animals, (3) jin shaped like a human such kuntilanak, genderuwo, including those like a human but not perfect, as the Prophet SAW said:

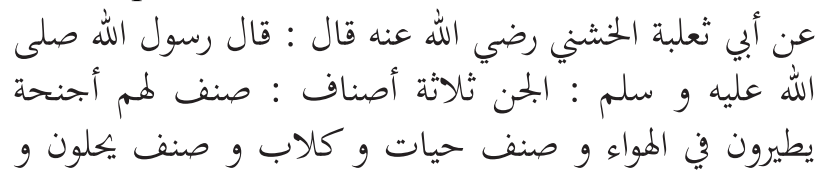

\footnotetext{
${ }^{22} \mathrm{http}: / / \mathrm{www}$. seputarduniaislam.com/2015/11/luar-biasamanfaat-membaca-al-Qur'an.html? $\mathrm{m}=1$, retrieved on Desember 2015.
}

$$
\text { يظعنون (رواه الحاكم) }
$$

"From Abi Tsa'labah al-Khsyaniy ra. said: The Messenger SAW said: there are three types of jin who have wings that can fly in the air, jin in the form of snakes and dogs and demons that dwell in its place and move" (HR. al-Hakim).

Al-Hakim said this hadith quality is Saheeh al-isnad, but al-Bukhari and Muslim were not narrated, as well as al-Zahabi in his book alTalkhis declared shahih. Al-Suyuthi mentions this hadith is also narrated by Thabrani alBaihaqy and in his book al-Asmak of Abi Tha'labah al-Khasyaniy, and declared as Sahih Hadits. ${ }^{24}$

In another narration of Ibnu Abi al-Dunia mentions in his book Makaid al-syaithan words of the Prophet SAW dari Abu Darda ra:

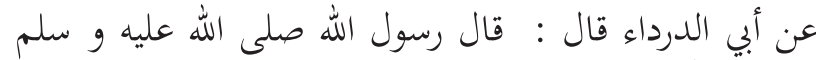

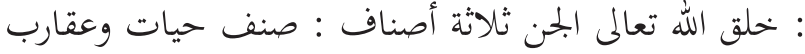

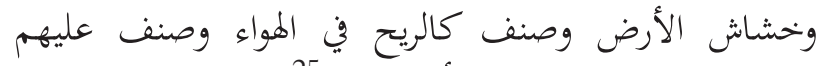
الحساب والعقاب (رواه ابن أبي الدنيا)

"From Abi Dardak said: Rasulullah SAW said: Allah created jin of three types, namely types of snakes, scorpions and reptiles, the kind of wind that flew in the air and the kind will be hisab and iqab (doom)."

Based on the distribution of jin above can

\footnotetext{
${ }^{23}$ Muhammad bin Abdillah Abu Abdillah al-Hakim al-Nisabury, al-Mustadzrak 'ala al-Shahihain, Muhaqqiq: Musthofa Abd al-Qadir 'Atha, Juz 2 (Beirut: Dar al-Kutub al-Ilmiyah, 1990), 495.

${ }^{24}$ Jalal al-Din Abd al-Rahman bin Abi Bakar bin Muhammad bin Sabiq al-Din al-Suyuthi, al-Jami' al-Shaghir min Hadis alBasyir al-Nazir, Juz 1 (Maktabah Syamilah), 334.

${ }^{25}$ Ibnu Abi al-Dunia, Makaid al-Syaithan, juz 1 (Maktabah Syamilah), 23; this hadis is also narrated by Imam al-Suyuthi in his book Tamhid al-Farsy fi al-Khishal al-Mujibah li zhill al-'Arsy, Juz 1 (Maktabah Syamilah), 15, by sanad from Abu Ya'la told to us al-Husain al-Saud, Abu Usamah told to us, Yazid bin Sinan Abu Farwah told to us, Abu Munib al-Himshi told to me, from Yahya bin Abi Katsir from Abi Salmah from Abu Dardak Rasulullah SAW said (Like Hadits before), Ibnu Hajar al-Asqalani mention the similar hadits in accordance with book al-Mathalib al-'Aliyah bi Zawaid al-Masanid al-Tsamaniyah, Juz 14 (Maktabah Syamilah), 193.
} 
be understood that there is a jin that are gaseous or wind which can certainly enter and flow in human body through the blood stream as well as the words of the Prophet SAW narrated by Syofiyyah binti Huyay:

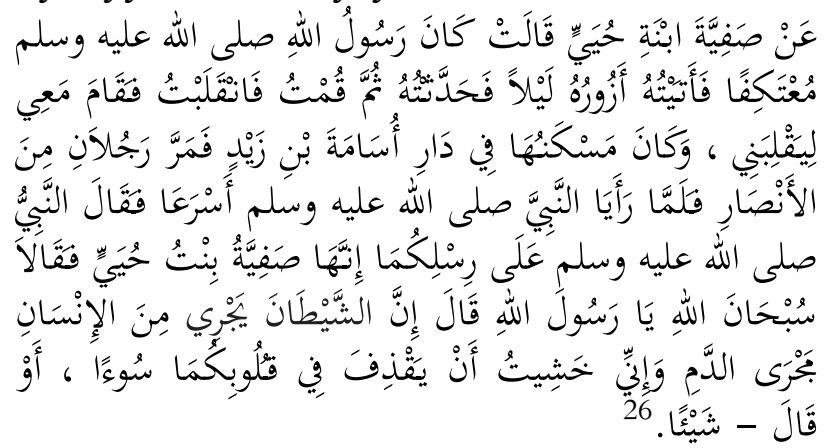

"From Shafiyyah binti Huyay, said:" Once the Prophet i'tikaf ago I went to visit him at night, talking and stood up to leave, then he stood up, drive me. The place is in the house of Usamah bin Zaid, and two men from Bani Ansar passed by, and when they saw the Prophet, they speed up pace, the Prophet said: "Stop you two, she is Shofiyah bint Huyay." They say "Subhanallah $O$ Messenger of Allah. "He said again," Look Syiathan runs on the child's bloodstream of Adam. And I worry that he dumped evil in hearts of both of you. "- Or he said:" something” (HR. Bukhari).

Ustadz Aliran stated that type of jin in form of gaseous or wind which can bring a variety of diseases for humans because they are in bloodstream, either in the form of physical ailments such as blood pressure and high cholesterol, deep vein thrombosis, excess uric acid and others as well non-physical disease. Jin is trying to interfere and mislead people belonging to syaithan, and syaithan of jin through their representatives namely devil, had expressed hostility to humans and will try to come upon them from in front of, rear, left and right as Allah says in Surah alA'raf : 16- 17:

${ }^{26}$ Al-Bukhari, Juz 4, 150

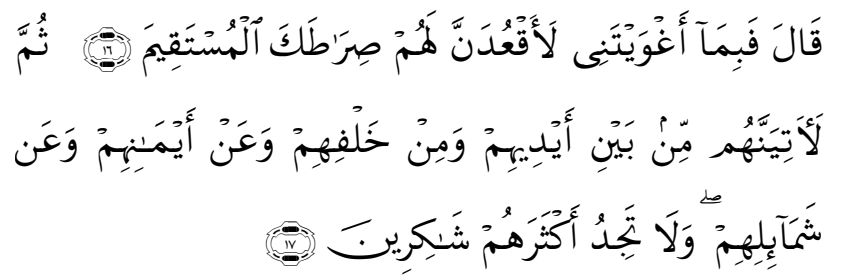

"[Satan] said, "Because You have put me in error, I will surely sit in wait for them on Your straight path (16) Then I will come to them from before them and from behind them and on their right and on their left, and You will not find most of them grateful [to You]." (17)

Imam al-Qurthubi stated the interpretation of this verse from Sufyan from Mansur from al-Hakam bin Utaibah that the meaning of "in front of" is their world, it is meant devil tried to turn the children of Adam from the world so that they deny or forget the verses of Allah in the world and forget the news previous people. "from behind" the point of afterlife so they forget, "from the right" meant that kindness and judge actions of their religion, "from the left" means evil, devil will encourage them to follow their own lusts. ${ }^{27}$

From this verse is understood that devil or syaithan from among of jin are always trying anytime, anywhere and in any way to interfere humans in order they strayed from the path his Lord, including by way of bringing disease. Therefore, the treatment of both disease (physical and non-physical diseses) must necessarily with ruqyah Syar'iyyah.

Similar views were delivered by psychiatrist, Maisarah, ${ }^{28}$ that all disease treatments are

\footnotetext{
${ }^{27} \mathrm{Abu}$ Abdillah Muhammad bin Ahmad bin Abi Bakar bin Farh al-Anshary al-Khazarjy Syams al-Din al-Qurthuby, al-Jami' $l i$ Ahkam al-Qur'an (Tafsir al-Qurthuby), Juz 7 (Cairo: Dar alKutub al-Mishriyah, 1964), 176.

${ }^{28}$ Full name. Dr. Hj. Maisarah, Zas, SpKJ, a Doctor of psychiatrist graduated from S1 of Medical School, University of Andalas Padang in 1986, and S2 of Medical School, Indonesia University of Department of SPKJ (psychiatrist) in 2001, has been and is being written several Islamic books to relating to health, such Muslim Identity Enlightenment, Supreme Invite on Earth for
} 
actually a treated by al-Qur'an and honey (or herbs), while medical treatment with medicine is not a treatment sunnah of Prophet Muhammad. Therefore, for those who used medication of all diseases are only al-Qur'an and honey as found in al-Sunnah. Medical treatment does not examine disease cause except things can be analyzed. In other words, medical treatment does not reach the existence of jin as a cause bring physical illness because jin cannot be observed and it only a study of clergy. Whereas, based on data obtained, there are many physical illnesses believed to be caused by disturbance jin which are not able to be handled by doctors such as skin diseases and headache which in turn can be cured by ruqyah.

Maisarah states concept of health in accordance with Islamic teaching associated with three elements used in humans, i.e. psycho, neuron and immunology. According to her, in human body God has created cure and immunological system against disease both medical or non-physical through food consumed on condition of food into the body is lawful and thayyib. If the food is not kosher food consumed both in terms of substance and in terms of how to acquire it, syaithan will be able to enter and flow into the blood causing various diseases. Likewise, if the food is kosher only meet the elements but not thoyyib (nutritious) it will make the body weaker, less resourceful capabilities so that it can bring in ignorance. If both requirements of food that God commanded to be met then someone are overwritten by the disease, it suggests these elements do not work particularly well, psycho which is the control center or a leader in human beings. If psycho person is not functioning properly then it cannot activate neuron or cells that contain natural remedies to combat all diseases immunological or immune system so the body does not function

Conservation and Reconstruction of Tauhid civilization in the Kingdom of Heaven and Earth. Interviews were conducted at RSJ Pekanbaru, on October 2016. that causes a person vulnerable to various diseases. So to fight the disease suffered by the body, it must first restore healthy psycho so that it can function well in neuron ordered body to fight disease.

Feature psycho healthy is if psycho and psychiatric faith in God, have patience, resignation properties and other properties described in al-Qur'an and al-Sunnah so that it makes calm psycho and become a leader for the whole body. When ill psycho restores into healthy psycho through reading or listening verses in al-Qur'an, it in Sunnah of the Prophet becomes as a worship called ruqyah.

Furthermore, the strength of immunology in neuro is obtained through lawful food and thoyyib. As the command of God to all human beings to consume only kosher food and thoyyib in surat al-Baqarah:

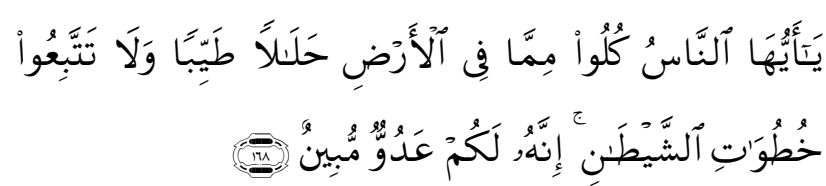

"O mankind, mankind, eat from whatever is on earth [that is] lawful and good and do not follow the footsteps of Satan. Indeed, he is to you a clear enemy" (al-Baqarah: 168).

Kosher foods are foods that are justified by Syari'ah to be consumed either kosher in terms of substance or how to get it, while thoyyib food contains high nutrition to nourish body. Thus, Three elements concept in the body described above, humans essentially no longer need additional medicines, but it is enough to make three elements in human beings has properly function so that it can prevent disease or repel disease that has been suffered by human body.

Based on the explanation above, it is understood that there are two forms medical illnesses cause namely interference or norinterference by jin and and purely physical symptoms. Medical illness caused by 
interference jin usually accompanied by psychological disorders such as emerging fears exaggerated without cause, the mind is not calm, irritable, unable to sleep well, physicians cannot detect type of actual disease, doctor treatment is not exhaustive and others, whereas that is not caused by interference jin usually not accompanied by psychological disorders.

The second case of the first physical illness have been researched namely patients suffering from acute skin diseases and acute gastritis accompanied with headaches believed to be physical pain caused by disorders of $j$ in because it was accompanied by a psychological disorder so medical treatment undergone by patients did not produce healing perfectly, but it only with ruqyah Syar'iyyah therapy both disease appointed by Allah SWT. This is a strong indication that ruqyah Syar'iyyah be a very effective way to get treatment for healing from Allah, as well as medication is also a means for medical treatment where healing comes only from Allah SWT. From both of cases are no doubts that ruqyah therapy become mainstay of treatment of physical illness.

The third case is a housewife suffering from headaches hereditary could come anytime. When data is obtained, patient has not received recovery, but ruqyah would continue to do so with a strong expectation of God to heal. Based on the experience of ruqyah person, there is no certainty of a patient will get relief after undergoing several times ruqyah, whether after doing the first ruqyah, second, third and so forth. In principle it is simply an effort of sunnah Rasulullah SAW. This is evidence brings healing solely belong to Allah. He sometimes gives by the effort of ruqyah Syar'iyyah and also through other means. Likewise, in the fourth case of patient of Desmoplastic cancer diseases. After conducting the first and second ruqyah, patient feel the change of pain relief, a feeling of calm and can sleep well, it's just physical condition is still weak, but at initiative of family did not proceed with the next ruqyah. According to writer, the patient under no circumstances should continue next ruqyah and accompanied by consuming or entering lawful food and thoyyib (nutritious) for body. The medical treatment was continued by giving treatment lawful.

The fifth case until eight i.e. tonsillitis, toothache, sore eyes and typhoid, all patients receive healing with ruqyah Syar'iyyah therapy whereas before they saw the doctor and did not get healing. So it is the case of the ninth, HIV disease declared negative by the doctor after undergoing ruqyah Syar'iyyah therapy three times while HIV virus in medical treatment has not found a cure. Ruqyah HIV disease process is accompanied with liquid cure from Tapak Liman leaf juice with ginger. It cannot know which of two forms of treatment is an effective cure HIV virus, whether ruqyah reading or liquid from Tapak Liman juice and ginger or a combination of two can be separated without one of the two. But until now there has been no explanation from scientists about the function of Tapak Liman leaf and ginger can cure HIV virus.

Based on the explanation above, it can be believed that ruqyah Syar'iyyah be a good method of healing various diseases whether medical or non-medical disease is proper even take precedence over medical treatment. Treatment with ruqyah Syar'iyyah should conduct in accordance with al-Sunnah, because in addition serves to eliminate the disease, as well as worship Syar'iyyah ruqyah that is intended to get the reward from Allah SWT.

\section{Conclusion}

Based on the explanation above, it can be taken some conclusions as follows:

1. Ruqyah Syar'iyyah methods are applied by ruqyah person in Riau Province can be divided into two. First, Manual method is ruqyah method which merely read al- 
Qur'an verses, praying maktsurat and readings could understood in accordance with the Prophet Muhammad emulated and his companions. Second, a practical method is techniques developing in ruqyah for detecting disturbances without reciting verses of al-Qur'an first. There are five techniques namely techniques of touch, pat, pressure, swabs and a blow.

2. Ruqyah Syar'iyyah, either manual methods as well as practical methods are very effective in treating various diseases or medical physical, even ruqyah Syar'iyyah should take precedence over medical treatment. This is evident with the number of medical illness cases is not able to be handled by a doctor, can be cured with ruqyah Syar'iyyah with God's permission.

3. To obtain healing through ruqyah Syar'iyyah therapy, for those who suffered physical illness should cleanse themselves both soul by repentance and body by consume kosher food and thoyyibah (nutritious) and away from forbidden foods.

4. However, treatment efforts undertaken by somebody must be convinced that provide healing is solely the right of Allah. Human task is just trying but provision is God's. No human being can cure the disease with certainty either through medication treatment medis or ruqyah Syar'iyyah.

\section{Bibliography}

Abu Qasim, Sulaiman bin Ahmad al-Thabrani. al-Du'a. Juz 1. Beirut: Dar al-Kutub alIlmiyah, 1413.

al-Asqalani, Ibnu Hajar. al-Mathalib al-'Aliyah bi Zawaid al-Masanid al-Tsamaniyah. Juz 14. Maktabah Syamilah.
al-Bukhari, Muhammad bin Ismail bin Ibrahim bin al-Mughirah. al-Jami'al-Shahih. Cet. Ke-1. Kairo: Dar al-Sya’b, 1987.

al-Dunia, Ibnu Abi. Makaid al-Syaithan. Juz 1. Maktabah Syamilah.

Hasyisy, al-Syaikh Aliy. Silsilah al-Ahadis alWahiyah. Juz 1. Maktabah Syamilah.

http://www.seputarduniaislam.com/2015/11/ luar-biasa-manfaat-membaca-al-Qur'an. html?m=1.

http://www.sehatfresh.com/tumordesmoplastic/.

al-Nawawiy, Abu Zakariya Yahya bin Syarf bin Muray. al-Minhaj Syarh Shahih Muslim bin al-Hajjaj. Cet. Ke-2. Beirut: Dar Ihya' al-Turats al-'Araby, 1392.

al-Nisabury, Abu al-Husain Muslim bin al-Hajjaj bin Muslim al-Qusyairy. Sahih Muslim. Beirut: Dar al-Jil and Dar al-Afaq alJadidah, t.th.

al-Nisabury, Muhammad bin Abdillah Abu Abdillah al-Hakim. al-Mustadzrak 'ala al-Shahihain. Muhaqqiq: Musthofa Abd al-Qadir 'Atha. Juz 2. Beirut: Dar alKutub al-Ilmiyah, 1990.

al-Syaibani, Ahmad bin Hanbal Abu Abdillah. Musnad al-Imam Ahmad bin Hanbal. Juz 3. Kairo: Muassasah Qordova, t.th.

al-Suyuthi, Jalal al-Din Abd al-Rahman bin Abi Bakar bin Muhammad bin Sabiq al-Din. al-Jami' al-Shaghir min Hadis al-Basyir al-Nazir. Juz 1. Maktabah Syamilah.

al-Suyuthi. Tamhid al-Farsy fi al-Khishal alMujibah li zhill al- 'Arsy. Juz 1. Maktabah Syamilah.

al-Tabrani, Sulaiman bin Ahmad bin Ayub bin Mathir al-Lakhmiy al-Syamiy Abu alQasim. al-Mu'jam al-Kabir. Juz 5. Maktabah Syamilah. 